Ks. ZDZISŁAW KLIŚ

\title{
ŚREDNIOWIECZNE CYKLE PRZEDSTAWIENIOWE ŻYCIA, MĘCZEŃSTWA I CUDÓW ŚW. STANISLAWA, BISKUPA
}

Na temat ikonografii św. Stanisława biskupa powstało wiele opracowań. W tym krótkim zarysie autor chciałby podjąć kwestię cyklów męczeństwa Świętego związanych z Polską w sztuce średniowiecznej. Legendarium andegaweńskie zostaje tutaj umieszczone, ponieważ jest fundacją między innymi Elżbiety Lokietkówny, żony Karola Roberta i jest jedynym świadectwem zachowanej wczesnej ikonografii św. Stanisława, ujętej w cykl.

Zwykle w przedstawieniu sylwetki męczennika zwracano uwagę na cnoty, którymi charakteryzował się zmarły, naśladując i upodabniając się do Chrystusa. Stąd niekiedy były ilustrowane całe fragmenty ewangeliczne „historii Chrystusa" i wplecione w żywot świętego, ukazując podobieństwo wydarzeń ewangelicznych i życiorysu świętego. W przypadku św. Stanisława ikonografia oparta jest $w$ dużej mierze na relacjach kronikarskich i zapożyczeniach $z$ ikonografii Chrystusa i innych świętych.

Zestawienia wyobrażeń męczeństwa św. Stanisława dokonała Alicja Karłowska-Kamzowa, jednak nie wymieniła wszystkich scen występujących w poszczególnych cyklach'. Maria Kosińska zauważyła, że w Polsce „Jakkolwiek cykliczne przedstawienia żywotu powstawały już w wieku XIV, jednak właściwy rozwój ikonografii legendy zaczyna się ok. poł. XV w. (...)”, a „najwcze-

${ }^{1}$ A. K a r łow s k a - K a m z ow a, Wyobrażenia męczeństwa biskupa Stanistawa Szczepanowskiego (do polowy XVI w.), [w:] Interpretacja dzieła sztuki. Studia i dyskusje, Warszawa-Poznań 1976, s. 42. 
śniejsze zachowane polskie przedstawienia legendy św. Stanisława pochodza z pocz. XVI w." "2

Najstarszym zachowanym cyklem przedstawień życia, męczeństwa i cudu po śmierci św. Stanisława są miniatury w Legendarium andegaweńskim omówione przez Ewę Śnieżyńską-Stolot ${ }^{3}$, Ferenc Levardy ${ }^{4}$ i ks. Janusza Pasierba ${ }^{5}$. W Legendarium umieszczonych jest osiem scen: Wybór na biskupa, Wskrzeszenie komesa Piotra, Zabójstwo św. Stanislawa, Poćwiartowanie jego ciała, Strzezenie szczatek przez orly, Pogrzeb, Ukazanie się ludowi i Wskrzeszenie syna pewnego Węgra. Fundatorem dzieła był król węgierski Karol Robert i Elżbieta, jego żona (która zapewne zadbała o umieszczenie żywotu św. Stanisława biskupa w Legendarium), zaś ozdobił je malowidłami Hertul, malarz, który pochodził z Sopronu, był malarzem królewskim i studiował w Bolonii (stąd miniatury wykazują wpływ malarstwa bolońskiego). Miniatury o św. Stanisławie w Legendarium są ilustracją tekstu Złotej legendy, ukończonej najpóźniej w 1270 r., w której już zawarta jest legenda o uzdrowieniu węgierskiego chłopca. Wcześniej o wskrzeszeniu pewnego węgierskiego chłopca przez biskupa opowiada Legenda dominikanina Wincentego z Kielczy. Legendarium nie mogło powstać przed 1317 r. (datą kanonizacji św. Ludwika z Tuluzy, który w Legendarium ukazany jest jako święty) a ukończenie malowania kodeksu mogło nastapić w 1332 i 1333 r. (czasu wyjazdu Karola Roberta z synem Andrzejem do Neapolu) ${ }^{6}$.

Innym dziełem, w którym zawarte zostało życie i męczeństwo św. Stanisława, jest rzeźbiony tryptyk z około 1500 r. w kościele Mariackim w Krakowie. Główną scenę w szafie oltarza stanowi Zabójstwo św. Stanisława, a na skrzydłach ołtarzowych umieszczone są w kolejności sceny: Kupno wsi, Wskrzeszenie komesa Piotra, Świadczenie przed królem, Strzeżenie rozczłonkowanego ciala przez orły. W predelli umieszczone jest Złożenie do grobu, czyli pogrzeb Świętego ${ }^{7}$. Sokołowski odniósł tryptyk do ołtarza wieniawskiego, a Pagaczewski zestawił go ze srebrnym posażkiem św. Stanisława w kościele OO. Paulinów na Skałce w Krakowie i ornatem św. Stanisława fundacji Piotra

${ }^{2}$ M. K o s ińs k a, Zarys ikonografii św. Stanistawa bpa na podstawie zabtytków krakowskich do połowy XVI wieku, Sprawozdania Poznańskiego Towarzystwa Przyjaciół Nauk, 16, 1949, s. 98-99.

${ }^{3}$ E. Ś n i e ż y ń s k a - S t o l o th Ze studiów nad ikonografia legendy św. Stanisława bisku$p a$, ,Folia Historiae Artium” 8 (1972), s. 161-166, il. 1-2.

${ }^{4} \mathrm{~F}$. L e v a r dy, Wegierskie legendarium andegaweńskie, Wrocław-Budapeszt 1978. Tutaj zawarta jest pełna literatura przedmiotu.

${ }^{5}$ J. P a s i e r b, Życie, męka i chwata św. Stanisława w "Legendarium Andegaweńskim" (BAV VAT.LAT. 8541), ,Rocznik Historii Sztuki” 19 (1992), s. 45-63.

${ }^{6} \mathrm{~F}$. L e v a r d y, Wegierskie legendarium..., dz. cyt., s. 25-26, 40, 46-48; J. P a s i e r b, Życie, męka i chwata..., dz. cyt., s. 45-47.

${ }^{7}$ A. K a r ło w s k a - K a m z ow a, Wyobrażenia męczeństwa..., dz. cyt., s. 34, il. 4. 
Kmity w katedrze na Wawelu. Obaj za autora tryptyku uznali Stanisława Stwosza $^{8}$. Pagaczewski datował tryptyk na lata $1500-1515^{9}$. Andrzej M. Olszewski uznał, że nie należy łączyć autorstwa ołtarza mariackiego $\mathrm{z}$ ornatem Kmity, istnieją bowiem między nimi różnice stylistyczne i kompozycyjne ${ }^{10}$.

Z 1504 r. pochodzi relikwiarz na głowę św. Stanisława ufundowany przez królową Elżbietę Rakuszankę przy użyciu funduszów pozostałych po jej synach, królu Janie Olbrachcie i kardynale Fryderyku, staraniem biskupa Jana Konarskiego. Wewnątrz relikwiarza znajduje się sygnatura złotnika krakowskiego Marcina Marcińca. Sceny umieszczone na ściankach puszkowego relikwiarza to: Kupno wsi, Wskrzeszenie komesa Piotra, Świadczenie przed królem, Zamordowanie, Rozsiekanie zwlok, Orty strzegace ciala, Pogrzeb, Kanonizacja w Asyżu ${ }^{11}$.

Pod rokiem $1504 \mathrm{w}$ dotychczasowej literaturze umieszczano ornat ufundowany dla katedry wawelskiej przez Piotra Kmitę, w okresie kiedy był wojewodą krakowskim $^{12}$. Kmita pełnił ten urząd od $1501 \mathrm{r}$. do śmierci 15 kwietnia $1505 \mathrm{r}$. Zatem w tym czasie na pewno powstał ornat ze scenami z życia św. Stanisława. W krzyżu na tylnej stronie ornatu umieszczone są sceny: Kupno wsi, Wskrzeszenie komesa Piotra, Świadczenie przed królem, Śmierć św. Stanistawa, Rozsiekanie zwłok, Pogrzeb i Kanonizacja w Asyzu. Próba wiązania ornatu ze Stanisławem Stwoszem należy do kręgu hipotez ${ }^{13}$.

Dacie 1505 r., według Jerzego Gadomskiego, odpowiada styl kwater tryptyku z kościoła OO. Paulinów na Skałce w Krakowie. Na kwaterach umieszczone są sceny: Stanistaw napominajacy króla, Rozsiekanie zwłok św. Stanistawa, Pogrzeb św. Stanisława i Kanonizacja św. Stanisława. Warsztatowo tryptyk wykazuje związek z Mistrzem Poliptyku św. Jana Jałmużnika. Niektóre fizjonomie na przykład w scenie Św. Stanisław napominający króla zdradzają po-

${ }^{8}$ M. S o k o ło w ski, Studia do historii rzeźby w Polsce w XV $i$ XVI w., „Sprawozdania Komisji do badania historii sztuki w Polsce" 7 (1906), s. 100-105; J. P a g a c z e w s k i, Posag św. Stanisława w kościele oo. Paulinów na Skałce w Krakowie, Kraków 1927, s. 19-46.

${ }^{9}$ J. P a g a c z e w s k i, Posag św. Stanisawa..., dz. cyt., s. 45.

${ }^{10}$ A. M. O ls ze w s ki, O rzeźbach kilku późnogotyckich ottarzy matopolskich, „Biuletyn Historii Sztuki" 26 (1964) nr 4, s. 314-315.

${ }^{11}$ A. B o c h nak, Zabytki ztotnictwa późnogotyckiego zwiazane z kard. Fryderykiem Jagiellończykiem, „Prace Komisji Historii Sztuki” 9 (1948), s. 1-5, il. 1-10; Katalog Zabytków Sztuki w Polsce, t. 4, Miasto Kraków, cz. 1, Wawel, praca zbiorowa pod kierunkiem i redakcja J. Szablowskiego (tekst), Warszawa 1965, s. 117; J. S a m e k, Relikwiarz św. Stanisława z roku 1505 i inne tego typu relikwiarze w Polsce, ACr 18 (1986), s. 465-490.

${ }^{12}$ T. K r u s z y ń s ki , Ornat Piotra Kmity $i$ ołtarz św. Antoniego fundacji Kmitỏw w katedrze wawelskiej, Skarbiec katedry wawelskiej i Muzeum metropolitalne z. 6, 1930 r., s. 60.

${ }^{13}$ Sztuka w Krakowie w latach 1350-1550, katalog wystawy urządzonej w sześćsetną rocznicę założenia Uniwersytetu Jagiellońskiego pod redakcją A. Bochnaka, Kraków 1964, s. 193-194 , il. 94. 
krewieństwo $\mathrm{z}$ manierą czynnego jeszcze w pierwszym dziesięcioleciu XVI w. Mistrza Zwiastowania z Jodłownika. Ikonograficznie scena ta wykazuje zwiazki z malarstwem austriackim. Dla sceny Kanonizacji św. Stanistawa jako pierwowzór mogła posłużyć scena Ostatniej Wieczerzy, a w przedstawieniu Rozsiekania zwłok widoczne są elementy zaczerpnięte z ówczesnej rzeczywistości ${ }^{14}$.

Tryptyk z cyklem św. Stanisława w kościele parafialnym w Starym Bielsku Jerzy Gadomski zaliczył do warsztatu Mistrza Rodziny Marii. Powstał on po 1505 r. lub po 1507 r. W kwaterach tryptyku widnieją sceny: Kupno wsi, Wskrzeszenie komesa Piotra, Świadczenie przed królem, Zabójstwo św. Stanisława, Rozsiekanie zwłok, Strzeżenie przez orly i zrośnięcie się ciała św. Stanisława, Pogrzeb św. Stanistawa oraz Kanonizacja św. Stanislawa. Prof. Gadomski pisze, iż „nie można (...) wykluczyć, że malując tryptyk dla Starego Bielska, w scenie Pogrzebu św. Stanistawa, [malarz] korzystał z wzoru Schaufeleina (Ztożenie do grobu) z pierwszego norymberskiego wydania Speculum passionis"15.

W roku 1508 powstał tryptyk bodzentyński Zaśnięcia Matki Boskiej, wykonany przez czterech malarzy w warsztacie Marcina Czarnego. Został ufundowany przez biskupa Jana Konarskiego. Z tryptyku zachowały się: obraz środkowy, trzy dwustronnie malowane kwatery skrzydeł i predella. $Z$ czterech scen cyklu św. Stanisława na kwaterach malowanych przez tak zwanego „drugiego malarza" zachowały się: Wskrzeszenie komesa Piotra, Rozsiekanie zwłok i Pogrzeb św. Stanisława. Scena Pogrzebu św. Stanisłorwa została oparta na drzeworycie Złożenia do grobu Hansa Schaufeleina z wydanego w 1507 r. przez Ulryka Pindera Speculum passionis domini nostri Jesu Christi ${ }^{16}$.

Do warsztatu Mistrza Rodziny Marii działającego w pierwszej ćwierci XVI w. Jerzy Gadomski włączył tryptyk ze śś. Stanisławem, Wacławem i Archaniołem Michałem z kościoła parafialnego w Skrzyszowie, którego skrzydła $\mathrm{z}$ historią św. Stanisława znajdują się w Muzeum Diecezjalnym w Tarnowie. Na jednym ze skrzydeł widnieja malowane sceny: Zabójstwa św. Stanisława i Wskrzeszenia Piotrowina ${ }^{17}$.

Ten sam badacz zaliczył poliptyk z kościoła parafialnego w Korzennej do warsztatu Mistrza tryptyku z Wójtowej. Na rewersach ołtarza widnieją: Wskrzeszenie komesa Piotra, Świadczenie przed królem, Pilnowanie zrastających się zwlok przez orly i Pogrzeb św. Stanislawa. Do poliptyku przynależy zapewne również kwatera ze sceną Kupna wsi ${ }^{18}$.

${ }^{14}$ J. G a d o m s k i, Gotyckie malarstwo tablicowe Matopolski 1500-1540, Warszawa-Kraków 1995, s. 57-58, il. 16-19, II.

${ }^{15}$ Tamże, s. $73,76-79$, il. 60-67, X.

${ }^{16}$ Tamże, s. 59-61, 63, i1. 26-27.

${ }^{17}$ Tamże, s. 75, il. 91 .

${ }^{18}$ Tamże, s. $101-104$, il. 204, 208-210. 
Na poliptyku z lat 1508-1509 z kaplicy złotników w kościele św. Marii Magdaleny we Wrocławiu wyrzeźbione są sceny: Kupno wsi, Wskrzeszenie komesa Piotra, Świadectwo przed królem (scena główna w szafie ołtarza), Zabójstwo św. Stanisława, Ćwiartowanie zwłok. Pozostałe sceny są malowane: Orty strzegqce zwłok, Zrośnięcie się ciała, Kanonizacja św. Stanistawa, Św. Stanistaw ukazujacy się biskupowi Rajmundowi ${ }^{19}$. Anna Ziomecka przytacza wypowiedź Sławskiej, która zauważyła odrębność redakcji ikonograficznej poliptyku wrocławskiego od wzorów krakowskich i małopolskich. Wykonawca przybył z zewnątrz, niedługo zabawił na Ślasku, a jego bliższe środowisko nie zostało dotychczas wyraźnie określone ${ }^{20}$.

Ze Szczepanowa, jak podaje ks. Władysław Smoleń, pochodzą skrzydła $\mathrm{z}$ trzech ołtarzy $\mathrm{z}$ lat od 1510 do 1520 , znajdujące się w Muzeum Diecezjalnym w Tarnowie. Przedstawiają historię życia, śmierci i kanonizacji św. Stanisława ${ }^{21}$.

Tryptyk z kościoła w Pławnie ze względu na malowidła związano z Hansem Suessem z Kolumbachu. Rzeźbiarska część tryptyku mogła być wykonana według jego rysunków, niekoniecznie w jego pracowni. Tryptyk powstał zapewne w latach około 1511 lub 1514-1516, poniewaź na te lata przypada wykonanie przez Suessa innych dzieł związanych z Polska jak twierdzi Andrzej M. Olszewski ${ }^{22}$. Na tryptyku wyrzeźbiono sceny poświęcone św. Stanisławowi: Kupno wsi, Świadczenie przed królem, Zabójstwo św. Stanisława, Rozsiekanie zwtok, Przeniesienie zwtok $i$ Kanonizacja ${ }^{23}$.

Odpowiednikiem tryptyku z Pławna, jak uważa Janusz Kębłowski, jest tryptyk w kościele parafialnym w Kobylinie, powstały około $1518 \mathrm{r}$. Twórca tego oltarza korzystał z malarstwa Suessa i ilustracji Miechowity ${ }^{24}$. Tryptyk został ufundowany przez biskupa krakowskiego Jana Konarskiego i namalowany zapewne w warsztacie krakowskim. Najbardziej zaawansowaną stylowo scena (w kierunku rozwiązań renesansowych) jest Kupno wsi ${ }^{25}$.

${ }^{19}$ T. D o b r z e n i e c k i, Malarstwo tablicowe, katalog zbiorów, Warszawa 1972, s. 290-291 , il. $105 \mathrm{Ala}, 105 \mathrm{Alb}, 105 \mathrm{~B} 1 \mathrm{a}, 105 \mathrm{~B} 1 \mathrm{~b}$.

${ }^{20} \mathrm{~A}$. Z i om ecka, Ślaskie retabula szafowe $w$ drugiej potowie $X V$ i na poczatku $X V I$ wieku, „Rocznik Sztuki Śląskiej” 10 (1976), s. 132, il. 56.

${ }^{21}$ Wł. S m o le ń, Legenda Piotrowina w gotyckiej ikonografii św. Stanisława ze Szczepanowa, „Roczniki Humanistyczne" 23 (1975) z. 5, s. 11, il. 2-4.

${ }^{22}$ A. M. O Is z e w s k i, O rzeźbach, s. 315.

${ }^{23}$ T. D o br zen i e k i, Tryptyk z Ptawna, Warszawa 1954; H. i S. K o zak i e w i c z ow i e, Renesans w Polsce, Warszawa 1976, s. 87, il. 77.

${ }^{24}$ J. K ę b ł o w s k i, Dzieje sztuki polskiej, panorama zjawisk od zarania do wspótczesności, Warszawa 1987 , s. 98.

${ }^{25}$ M. W a li ck i, Gotyk, renesans, wczesny manieryzm, Warszawa 1963, nr 167-171; H. i S. K o z a ki e w i c zow i e, dz. cyt., s. 92-93. 
Innym dziełem jest już renesansowy poliptyk wieniawski ${ }^{26}$. Jak pisze Andrzej M. Olszewski, w reliefach Zabójstwa św. Stanisława i Strzeżenia zwłok przez orty (tryptyk opatrzony jest data 1544 r.) dostrzegamy analogie do ołtarza w kościele Mariackim w Krakowie, ale w lustrzanym odbiciu. Stąd wniosek, że jeden $\mathrm{z}$ artystów oparł się na odbitce graficznej. Autorem ołtarza mógł być snycerz Jan, współpracownik Tauerbacha i rzeźbiarz części głów wawelskich ${ }^{27}$.

Jednym z wyżej wymienionych przez ks. Smolenia skrzydeł ołtarzowych w Muzeum Diecezjalnym w Tarnowie zapewne są datowane na rok 1503 przez ks. Władysława Szczebaka kwatery tryptyku ze Szczepanowa, na których znajdują się sceny: Narodzenia św. Stanistawa, Chrztu św. Stanisława, Kupna wsi, Świadczenia przed królem, Zabójstwa św. Stanisława, Pogrzebu, Przybycia króla Bolestawa na Węry, Debaty papieża Innocentego IV $i$ kardynałów nad świętościq Biskupa Stanistawa, Ukazania się św. Stanistawa kardynatowi Reginaldowi, Prośby kardynata Reginalda, aby ogłosił Biskupa Stanistawa świętym, Kanonizacji i przeniesienia relikwii w Krakowie przed uroczystościq ogtoszenia kanonizacjit $^{28}$. Jerzy Gadomski uznał, że styl obrazów bliższy jest dacie 1553 niż $1503^{29}$. Malowidła wykazują już cechy renesansowe.

Pomijając późne renesansowe dzieła, szczególnie te jak nastawa ołtarzowa w Wieniawie i ze Szczepanowa, w kolejności przedstawień w ołtarzach gotyckich należałoby przejść do sceny Wyboru św. Stanisława na biskupa. Scena Wyboru św. Stanisława na biskupa znajduje się tylko w Legendarium andegaweńskim i została szeroko omówiona przez ks. Pasierba. Posługując się źródłami pisanymi zwrócił on uwagę na czas i miejsce wyboru, konsekratora, który nakłada mitrę na głowę Świętego, duchownych, szaty liturgiczne św. Stanisława i konsekratora, wreszcie stwierdził, że uroczystość ma charakter religijny, bowiem nie ma tu ingerencji władcy dającego biskupowi pierścień i pastorał jako oznaki inwestytury. Poruszył także kwestię paliusza, jeżeli istotnie widnieje on na ramionach Biskupa, a ta część stroju św. Stanisława nie jest „ozdobą ornatu”, którą jest kolumna. Umieszczenie mitry na głowie św. Stanisława autor uznał za topos ikonograficzny właściwy dla miniaturzysty zdobiącego Legendarium, jako, że $w$ ten sposób pokazana została sakra biskupia św. Klemensa na fol. $58 \mathrm{r}^{30}$. Postawa klęcząca elekta i wkładanie mu na głowę mitry w Legendarium ${ }^{31}$ jak

${ }^{26}$ M. W a 1 i c k i, Renesansowy poliptyk wieniawski, Warszawa 1960.

${ }^{27}$ A. M. O 1 s z e w s k i, O rzeźbach, s. 315.

${ }^{28}$ Wł. S z c ze bak, Motywy ikonograficzne postaci św. Stanistawa Szczepanowskiego na podstawie zabytków z terenu diecezji tarnowskiej, "Tarnowskie Studia Teologiczne" 7 (1979), s. $221-228$, il. 5-9.

${ }^{29} \mathrm{~J}$. G a d o m s k i, Gotyckie malarstwo tablicowe Matopolski $1500-1540$, dz. cyt., s. 30.

${ }^{30} \mathrm{~J}$. P a s i e rb, dz. cyt., s. 47-50.

${ }^{31}$ F. L e va r d y, dz. cyt., il. XII, 2; XXVII, 1; XXX, 5; XXXIII, 3; XXXIV, 3; XXXVI, 2; XXXVII, 2: XXXIX, 2; XL, 4; LI, 1; LVI, 1. 
również w sztuce włoskiej ${ }^{32}$ jest powszechnym typem ikonograficznym, który porównywalny jest do Koronacji Matki Boskiej przez samego Chrystusa, lub przez Trójcę Swięta. Przy czym w Koronacji dokonywanej przez Chrystusa postacie Marii i Chrystusa ułożone są bokiem do widza i na wprost do siebie, zaś w Koronacji Matki Boskiej przez Trójcę Świętą Maria klęczy i ułożona jest niejednokrotnie prawie na wprost do widza ${ }^{33}$.

Do legendy Piotrawina w cyklu świętostanisławowskim przynależą: Kupno wsi, Wskrzeszenie komesa Piotra i Świadczenie komesa Piotra przed królem ${ }^{34}$. Opis Wskrzeszenia komesa Piotra, jak podaje ks. Smoleń, podobny jest do opowiadania o Aji w kronice Giselberta, kanclerza Baldvina VI, która z grobu zaświadczyła, że przekazała majątek klasztorowi św. Weldetrudy. Tutaj jednak nie ma wskrzeszenia kobiety, ale tylko występuje motyw głosu wydobywającego się z grobu. Bardziej zbliżona treściowo do legendy Piotrawina jest legenda o św. Fridolinie, misjonarzu irlandzkim, który działa w rejonie Bazylei. W opowiadaniu Urso przekazał majątek żeńskiemu klasztorowi św. Hilarego na wyspie Renu - Seckingen, który znajdował się pod opieką św. Fridolina. Po śmierci Urso jego brat chciał odebrać majątek. Wtedy św. Fridolin wskrzesił dobroczyńcę i ten zaświadczył przed sądem o przekazaniu majątku klasztorowi. Być może zmodyfikowana treść tych opowiadań została odniesiona do św. Stanisława i znalazła się w żywocie biskupa krakowskiego napisanym przez Wincentego z Kielczy w okresie starań o kanonizację ${ }^{35}$.

Spośród wymienionych powyżej dzieł sztuki scena Kupna wsi jest umieszczona: na tryptyku w kościele Mariackim w Krakowie, relikwiarzu na głowę św. Stanisława w katedrze wawelskiej, ornacie Kmity, tryptyku w Starym Bielsku, poliptyku z Korzennej, poliptyku z kaplicy złotników w kościele św. Marii Magdaleny we Wrocławiu, na tryptyku z Pławna, na tryptyku w Kobylinie. Oprócz ogólnych podobieństw we wszystkich dziełach scena ta jest inaczej przedstawiona, tak od strony kompozycji jak również strojów, w których występują bohaterowie przedstawienia. Zasadniczym elementem jest stół, przy którym dokonuje się zakupu wsi. W kwaterze tryptyku w kościele Mariackim

${ }^{32} \mathrm{G} . \mathrm{K}$ a f $\mathrm{t} \mathrm{a} \mathrm{l}$, Saints in Italian Art. Iconography of the Saints in the painting of North West Italy, Firenze 1985, szp. 445-446, il. 625.

${ }^{33}$ E. C e v c, Die Marienkronung aus dem Bozener Altar des Hans von Judenburg - Fragen Rekonstruktion, [w:] Internationale Gotik in Mitteleuropa, Herausgegeben von G. Pocht und B. Wagner, Graz 1990, s. 210-220; G. B r a u t i g a m, Die Bozener Tafel-Schicksale und Rekonstruktion, [w:] Internationale..., s. 221-232; I. F l o r, Hans von Judenburg II Die trinitarische Marienkronung - Zur Entfaltung eines neuen ikonographischen Themas, [w:] Internationale..., s. 233-252.

${ }^{34}$ W. S m o l e ń, dz. cyt., s. 5-14.

${ }^{35}$ Tamże, s. 7-8. 
w Krakowie św. Stanisław siedzi w głẹbi sceny przy krótszym końcu długiego stołu, natomiast komes Piotr siedząc przy stole, na pierwszym planie, zagarnia pieniądze. Pozostali uczestnicy sceny stoją w głębi, po lewej stronie przedstawienia. W relikwiarzu na głowę św. Stanisława i w kwaterze ołtarza ze Szczepanowa, którą publikuje ks. Smolen ${ }^{36}$, kompozycja obrazu wygląda inaczej. Stół przebiega przez prawie całą szerokość sceny i dopiero za nim zasiadają św. Stanisław i komes Piotr. Na ornacie Kmity stół stoi pośrodku sceny. Św. Stanisław podchodzi do niego $\mathrm{z}$ lewej strony, zaś komes Piotr siedzący za stołem naprzeciwko Świętego zagarnia ręką przekazaną mu sumę. Towarzyszący biskupowi duchowni stoją z tyłu, za nim lub obok. Na tryptyku w Starym Bielsku kompozycja jest nieco podobna do tej na tryptyku mariackim, ponieważ św. Stanisław zasiada za stołem w głębi sceny, a komes Piotr tyłem zwrócony do widza siedzi za stołem na pierwszym planie. Po prawej stronie sceny stoją duchowni i świeccy, swiadkowie przeprowadzanej transakcji. W tryptyku z Korzennej ułożenie św. Stanisława i komesa Piotra jest podobne do kompozycji na relikwiarzu na głowę św. Stanisława. Obaj siedzą za stołem „przecinającym wzdłuż” scenę Kupna wsi. Kompozycje na poliptyku wrocławskim, tryptyku z Pławna i w Kobylinie są podobne do siebie. Kontrahenci siedzą naprzeciw siebie, św. Stanisław po lewej stronie stołu, zaś komes Piotr naprzeciwko niego. W tle znajdują się świadkowie zakupu wsi. Św. Stanisław zwykle występuje w szacie duchownej, różnego kroju, jest to głównie biskupia mozzetta nałożona na ramiona. W przedstawieniach ze Szczepanowa ${ }^{37}$ i z Pławna oraz w Kobylinie Święty ma na głowie mitrę. W wyobrażeniu w Pławnie ma na sobie nałożoną kapę. Świeccy, jak to zauważa ks. Kruszyński w przypadku ornatu Kmity, są w szerokich płaszczach z obszernymi kołnierzami, zwanymi diplois, od podwojenia, czyli podbijania podszewką jedwabną ${ }^{38}$.

Cudu wskrzeszenia, oprócz wspomnianych powyżej przez ks. Smolenia świętych, według Wincentego z Kielczy, co zauważa ks. Pasierb, dokonali również arcybiskup Trewiru św. Materna i św. Spirydion, biskup Aten ${ }^{39}$. W ikonografii św. Stanisław wskrzeszający komesa Piotra występuje w mitrze, ornacie lub kapie (ornat Kmity), stoi nad grobem lub przyklęka (relikwiarz na głowę św. Stanisława i ornat Kmity). W Legendarium za św. Stanisławem stoi tylko duchowny $\mathrm{z}$ księgą $\mathrm{w}$ rękach, w pozostałych przedstawieniach, wspomnianych powyżej, są liczniejsi świadkowie wydarzenia. Na ornacie Kmity Swięty zdaje się podawać rękę komesowi Piotrowi, na kwaterze z Korzennej trzyma go za rękę (podobnie na epitafium z około $1520 \mathrm{r}$. Stanisława Chroberskiego i Stani-

\footnotetext{
${ }^{36}$ Tamże, il. 2.

${ }^{37}$ Tamże, il. 2.

${ }^{38}$ T. K r u s z y ńs k i, dz. cyt., s. 58.

${ }^{39}$ J. Pasi e r b, dz. cyt., s. 50 .
} 
sława Tarły w Katedrze Sandomierskiej ${ }^{40}$ ). Na tryptyku ze Skrzyszowa, Korzennej, w Starym Bielsku, w Bodzentynie i w kwaterze oltarza ze Szczepano$\mathrm{wa}^{41}$ św. Stanisław dotyka pastorałem komesa Piotra (zgodnie $\mathrm{z}$ wersją Wincentego z Kielczy i tym, co jest widoczne na fresku w bazylice św. Franciszka w Asyżu ${ }^{42}$ ), a na ołtarzu z Korzennej trzyma go w ręku. Na relikwiarzu na głowę św. Stanisława, na ornacie Kmity, na ołtarzu z Korzennej w tle widoczne jest wejście do kościoła, zaś na ołtarzu mariackim w Krakowie i tryptyku w Starym Bielsku w pejzażu widnieje cały budynek kościelny.

Scena Świadczenia komesa Piotra przed królem również zaprojektowana została różnorodnie, chociaż zasadniczy schemat wydaje się być zapożyczony z przedstawień Pasji Chrystusa: Sądu Chrystusa przed Annaszem, Kajfaszem, Piłatem i Herodem, w przypadku kiedy król ukazany jest z boku sceny i z drugiego krańca obrazu podchodzi komes Piotr i św. Stanisław (ołtarz w bazylice Mariackiej w Krakowie, poliptyk z Wrocławia), czasem trzymający komesa Piotra za rękę, jak to jest przedstawione na ornacie Kmity. Inną wersję stanowi realizacja: na relikwiarzu na głowę św. Stanisława, na kwaterze ołtarza w Starym Bielsku, w której król siedzi w centrum sceny. Taka kompozycja mogła być zapożyczona $\mathrm{z}$ przedstawień króla na pieczęciach majestatycznych i $\mathrm{w}$ obrazach ukazujących go jako władcę. Pośrednią wersję zastosowano na ołtarzu z Korzennej, w którym król siedzi pośrodku sceny, ale bokiem zwrócony z lewa ku prawej stronie obrazu i z lewej strony podchodzi do niego komes Piotr ze św. Stanisławem.

Wyjątkową sceną w nastawie ołtarzowej ze Skałki w Krakowie jest przedstawienie: Św. Stanistaw napomina króla. Profesor Gadomski dość szczegółowo zestawił tę scenę z kilkoma przykładami w malarstwie austriackim. Zauważył, że „biegnąca $w$ głąb ulica ze studnią przypomina perspektywę w tle Męczeństwa św. Thiemona (Teodmardusa z Salzburga) - obrazu dolnoaustriackiego Mistrza Męczeństwa Wszystkich Świętych z lat 1495-1500 (...). Z kolei patetyczny gest przedstawionej na dalszym planie kobiety unoszącej ręce na podobieństwo rozpaczających matek w Rzezi niewiniatek lub Marii Magdaleny w Opłakiwaniu należy do motywów o genezie włoskiej, podejmowanych przez malarzy austriackich. Krystyna Secomska nazwała twórcę obrazów ze Skałki «prowincjonalnym naśladowca Mistrza Epitafium Winklera», przy czym wiedeński malarz, zdaniem autorki, miał też istotny udział w ukształtowaniu stylu Mistrza Poliptyku św. Jana Jałmużnika"43.

${ }^{40}$ W. S m o l e ń, dz. cyt., s. 10 , il. 5.

${ }^{41}$ Tamże, il. 3.

${ }^{42}$ G. T. K a ft a l, Saints in Italian Art. Iconography of the Saints in Tuscan Painting, Firenze 1986, szp. 947-948, il. 1060.

${ }^{43}$ J. G a d o m s k i, Gotyckie malarstwo tablicowe Matopolski 1500-1540, s. 57-58. 
Jak stwierdził Marek Walczak, formuła pokazania męczeństwa przed ołtarzem, jak to było w przypadku św. Tomasza Becketa, znalazła kontynuacje w Europie Środkowej, w ikonografii św. Stanisława ${ }^{44}$. Jednak - jak pisze Alicja Karłowska-Kamzowa - wyobrażenia zabójstwa biskupa przy ołtarzu, na przykład Tomasza z Canterbury, nie dokonują się podczas aktu podniesienia. Schemat redakcji plastycznej Zabójstwa św. Stanisława, ze względu na moment podniesienia (elevatio), przypomina przedstawienia Mszy św. Grzegorza ${ }^{45}$. Na wszystkich powyższych przedstawieniach Zabójstwa św. Stanisława, Święty unosi hostię w czasie podniesienia. Jedynie w Legendarium ma na głowie mi$\operatorname{tre}^{46}$. W Legendarium, w Starym Bielsku i Skrzyszowie miecz króla Bolesława dotyka tyłu głowy św. Stanisława. Na malowidle w kościele św. Katarzyny w Gdańsku ${ }^{47}$, na ołtarzu mariackim w Krakowie, w relikwiarzu na głowę św. Stanisława, w ornacie Kmity król ukazany jest w chwili uniesienia miecza, aby Świętego uderzyć w tył głowy.

W Legendarium, na relikwiarzu na głowę św. Stanisława, na ornacie Kmity, na ołtarzu Paulinów ze Skałki w Krakowie, na ołtarzu w Starym Bielsku, na poliptyku z Wrocławia, na tryptykach w Pławnie i w Kobylinie ukazane jest Poćwiartowanie ciala św. Stanistawa. We wszystkich przedstawieniach kompozycja obrazu jest inna. Na wszystkich obrazach służba królewska ćwiartuje zwłoki Świętego. W scenach w Legendarium, na ołtarzu ze Skałki, na ołtarzu z Pławna, w Kobylinie i na kwaterze ołtarzowej z 1521 r. w kościele św. Mikołaja $w$ Poznaniu ${ }^{48} \mathrm{w}$ wydarzeniu uczestniczy król. W Legendarium wydaje polecenia palcem wskazującym prawej ręki. Na ornacie Kmity, ołtarzu ze Skałki, z Pławna i w kościele św. Mikołaja w Poznaniu ukazano rybę pływającą w sadzawce, która połknęła palec św. Stanisława. Niekiedy łączono scenę Poćwiartowania zwlok ze sceną Strzeżenia ciala przez orly (ornat Kmity, ołtarz ze Skałki i na kwaterze poznańskiej). Na skrzydle ołtarza wrocławskiego wyobrażono wywleczenie zwłok $\mathrm{z}$ kościoła dla ich poćwiartowania. Jest to jedyny znany przykład takiej sceny ${ }^{49}$. Na ołtarzu w Kobylinie przedstawione jest ćwiartowa-

${ }^{44}$ M. W a l c z a k, „Alter Christus”. Studia nad obrazowaniem świętości w sztuce średniowiecznej na przykładzie św. Tomasza Becketa, Kraków 2001, s. 284.

${ }^{45}$ A. K a r to w s k a - K a m z o w a, dz. cyt., s. 28, 33-34.

${ }^{46} \mathrm{~J}$. P a s i e r b, dz. cyt., s. 52.

${ }^{47}$ Być może jest to fragment większego cyklu żywotu św. Stanisława biskupa. W każdym razie malarz w typie oprawcy w scenie Zabójstwa św. Stanistawa nawiązał do wzorów Mistrza ES (J. D o m a s ł o w s k i, Pomorze Wschodnie, [w:] Gotyckie malarstwo ścienne w Polsce, red. A. Karłowska-Kamzowa, Poznań 1984, s. 134, il. 206).

${ }^{48}$ Zapewne na ołtarzu znajdował się cykl poświęcony życiu św. Stanisława biskupa (A. K a r ł ow s k a - K a m zow a, dz. cyt., s. 34,42 ).

${ }^{49}$ Tamże, s. 34. 
nie żywego jeszcze św. Stanisława siedzącego na ziemi. We wszystkich przedstawieniach poćwiartowanie ciała dokonuje się na zewnątrz kościoła, ukazanego w tle sceny.

Trzynastowieczne przedstawienia rozczłonkowanego ciała św. Stanisława, jak również przedstawienia zrośniętego ciała, strzeżonego przez cztery orły: na choragwi kanonizacyjnej, na plakiecie pokanonizacyjnej i w portalu kościoła w Starym Zamku stanowią świadectwa powstawania tej sceny u początków kultu pokanonizacyjnego św. Stanisława ${ }^{50}$. Na ołtarzu w bazylice Mariackiej i w tryptyku z Korzennej zrośnięte ciało św. Stanisława leży na ziemi i strzegą go cztery orły. Leżący na ziemi św. Stanisław przypomina Chrystusa w scenie Opłakiwania. Podobnie zrośnięte ciało zostało pokazane na poliptyku z Wrocławia. W Legendarium, na relikwiarzu na głowę św. Stanisława, w tryptyku w Starym Bielsku i w poliptyku wrocławskim na ziemi leżą jeszcze rozczłonkowane szczątki św. Stanisława strzeżone także przez cztery orły. We wszystkich trzech przedstawieniach zaznaczona jest odcięta głowa św. Stanisława, otoczona nimbem i ukazana w pozycji pionowej.

Złożenie ciała św. Stanisława w grobie, w sarkofagu, przypomina scenę Złożenia Chrystusa do grobu. W Legendarium w pogrzebie św. Stanisława bierze udział trzech biskupów. Jeden z nich bezpośrednio zajmuje się ciałem, dwaj inni stoją powyżej. Jak pisze ks. Pasierb: „obecność biskupów w pogrzebach świętych jest także swoistą manierą miniaturzysty Legendarium: często jest ich kilku - np. przy pogrzebie św. Marka aż czterech (fol. 43r), a św. Fabiana dwóch (fol. 47r)",51. Podobnie trzech biskupów występuje w scenach: w tryptyku ze Skałki, w tryptyku w Starym Bielsku, w tryptyku bodzentyńskim. Dwóch biskupów (?) pokazanych jest na relikwiarzu na głowę Świętego, na tryptyku z Korzennej, natomiast jeden biskup znajduje się w scenie Pogrzebu św. Stanisława na ornacie Kmity. W przedstawieniach obok biskupów występują także duchowni z tonsurami na głowie.

Na relikwiarzu na głowę św. Stanisława przedstawiona została kanonizacja św. Stanisława, w której biorą udział: papież w tiarze na głowie, dwaj kardynałowie w kapeluszach kardynalskich, i duchowny wydobywający czaszkę z grobu. Obok piszczeli i czaszki widnieje cała postać Świętego, który ukazuje się osobie klęczącej przed grobem. W ornacie Kmity papież, w triarze na głowie, siedzi na tronie i przyjmuje, zapewne czaszkę Świętego od duchownego, który

${ }^{50}$ J. P i e tr us i ń sk i, Portal św. Stanisława w Starym Zamku, „Biuletyn Historii Sztuki” 30 (1968) nr 3, s. 346-355; Tenże, Jak wyglqdat wizerunek kanonizacyjny św. Stanistawa?, „Rocznik Historii Sztuki” 17 (1988), s. 35-41.

${ }^{51}$ J. P a s i e r b, dz. cyt., s. 57. 
przed nim klęczy. Na kolanach papieża leży otwarta księga. W głębi sceny biskup w tiarze i duchowni pochylają się nad grobem św. Stanisława. Stojący za papieżem duchowny okadza szczątki św. Stanisława. Na kwaterze w Starym Bielsku papież siedzący pod baldachimem odczytuje zapewne dekret kanonizacyjny w obecności trzech kardynałów i biskupów, z których jeden trzyma prawdopodobnie czaszkę św. Stanisława. Postać św. Stanisława została ukazana w tle na choragwi lub obrazie. Nieco inaczej wygląda Kanonizacja św. Stanislawa na kwaterze tryptyku ze Skałki. Tutaj papież siedzi pod baldachimem w centrum sceny, wraz z kardynałami zgromadzonymi wokół stołu, co przypomina nieco scenę ewangelicznej Ostatniej wieczerzy.

Dwie sceny, które znajdują się w Legendarium: Stanisław objawia się ludowi i Wskrzeszenie węierskiego chtopca, mają miejsce jeszcze przed kanonizacją św. Stanisława. Pierwsza ze scen dokonała się w czasie między pogrzebem na Skałce a translacja, a druga ze scen przebiega w katedrze wawelskiej w relikwiarzu, pośrodku katedry wawelskiej ${ }^{32}$. Pierwsza ze scen ukazuje św. Stanisława w obłoku na wzór biblijnego objawienia się Boga w obłoku. Podobnie w Legendarium ukazany jest św. Władysław (Laszlo), unoszący się w powietrzu w chwili modlitwy ${ }^{53}$. Za św. Stanisławem widnieją trzej aniołowie, poniżej zaś klęczący ludzie. Druga ze scen przedstawia przyklękających przed relikwiarzem św. Stanisława rodziców chłopca, który zmartwychwstał za wstawiennictwem św. Stanisława. Na relikwiarzu umieszczone sq̨ obiecane przez rodziców trzy bochenki chleba i kogut jako dziękczynny dar za uratowanie syna. Relikwiarz romański, architektoniczny, w formie jednonawowej bazyliki, pokrytej dwuspadowym dachem, nawiązuje do tradycji wczesnochrześcijańskiej i średniowiecznej. Między innymi w takich „budowlach” umieszczano relikwie świętych.

Dokonane zestawienie cyklów z życia, męczeństwa i cudów po śmierci św. Stanisława, biskupa, pokazuje podobieństwa i różnice typologiczne w obrazowaniu wydarzeń spisanych przed kanonizacją i po kanonizacji Świętego. W zaprezentowanych przykładach trudno jest mówić o wiernym odwzorowaniu jakiegoś dzieła, można wskazać tylko na podobieństwa i koncepcje oparte na wzorach ikonograficznych, które zostały zaczerpnięte $\mathrm{z}$ istniejących już schematów utrwalonych w przedstawianiu Chrystusa lub świętych.

\footnotetext{
${ }^{52}$ Tamże, s. 58.

${ }^{53}$ F. L e vard y, dz. cyt., il. XLIV, 16.
} 


\section{Medieval cycles presenting the life and martyrdom of St. Stanislaus the Bishop and the miracles after his death \\ Summary}

The author has presented the state of research on the works existing in Poland as well as the ones connected with the country. Then he has compiled and discussed the same theme scenes. That compilation of cycles presenting the life and martyrdom of St. Stanislaus the Bishop and the miracles after his death shows typological similarities and differences in depicting the events recorded before and after the canonization of the Saint. Those examples do not represent any faithful imitation of some earlier work; one can only trace some similarities and concepts based on iconographic models already existing in depicting Christ and the saints. 